\title{
Uwagi na marginesie książki Micbała Gałędka Koncepcje i projekty nowego ustroju administracji dla przyszłego Królestwa Polskiego. Studium z dziejów myśli administracyjnej, Sopot 2017, 544 ss.
}

\author{
Abstract \\ Remarks on the Book by Michał Gałędek, Concepts and Projects of the $\mathcal{N}$ ew \\ Administrative System for the $\mathcal{F}_{\text {uture }}$ Kingdom of Poland. Studies on the History of \\ Administrative Thought (Sopot 2017, 544 pp.)
}

The work discussed here fills in an important gap in the research on the history of administrative thought in the Polish territory from the $18^{\text {th }}$ to the $20^{\text {th }}$ century. It must be emphasised that the book offers a competent and comprehensive study of the years 1813-1815. The goal of the author of the dissertation was to analyse the views on the form of the newly created administrative system, expressed along the progress of works - partially official - performed under the authorisation of Alexander I in 1813-1815, that is until the moment of providing constitutional regulations to the Kingdom. In accordance with the principles followed by the author, with which I entirely agree, the scientific analysis has comprised all the projects which had been drafted in that time (in particular: normative acts) as well as the opinions of the administrative system reform creators formulated in the course of works. In fact, this is how administrative thought should be interpreted, to be differentiated from the analysis of specific system solutions accepted as binding legislation. The source base constitutes a very strong point of the reviewed monograph. The author has used materials which had never been explored before. One must agree with the research conclusions included in the final passage. In his thesis, the author has confirmed the earlier ascertainments of legal historians: namely, stating that the works performed in 1813-1815 referred mostly to the solutions and experiences from the period of the Duchy of Warsaw, whereas references to the administrative system of the $18^{\text {th }}$-century Poland were visible only in a small minority of the reform creators.

Keywords: law, administrative system, history of administration, history of administrative thought, Kingdom of Poland (Congress Poland), administrative reforms

Słowa kluczowe: prawo, ustrój, historia administracji, historia myśli administracyjnej, Królestwo Polskie (Kongresowe), reformy administracyjne 
Monografia autorstwa Michała Gałędka stanowi realizację projektu finansowanego ze środków Narodowego Centrum Nauki. Stanowiła ona ponadto podstawę zakończonego pozytywnie w maju 2018 roku postępowania o nadanie stopnia naukowego doktora habilitowanego nauk prawnych. Autor podjął temat ważny, niebędący dotąd przedmiotem badań naukowych.

Omawiana praca wypełnia zarazem istotną lukę w badaniach poświęconych dziejom myśli administracyjnej na ziemiach polskich w okresie od XVIII do XX wieku. Jako pierwsza podjęła ten temat Maria Gromadzka-Grzegorzewska, analizując rozwój nauki administracji w II połowie XIX wieku1. Wkrótce ukazała się monografia autorstwa piszącego te słowa poświęcona myśli administracyjnej schyłkowego okresu Pierwszej Rzeczypospolitej². Myśl administracyjną Księstwa Warszawskiego przedstawił z kolei Paweł Cichoń ${ }^{3}$ O myśli administracyjnej w okresie Drugiej Rzeczypospolitej, ze szczególnym uwzględnieniem doktryny samorządu terytorialnego, pisali między innymi Marta Grzybowska, Adam Bosiacki oraz Monika Sidor'. Brakowało natomiast opracowania obejmującego okres Królestwa Polskiego doby konstytucyjnej. Obecnie lukę tę wypełnia rozprawa Michała Gałędka. Należy przy tym dodać, że stanowi ona dzieło kompetentne i w pełni wyczerpujące w odniesieniu do lat 1813-1815. Cieszy też informacja, że zamierza on kontynuować swe badania nad ustrojem administracyjnym Królestwa Polskiego doby konstytucyjnej, w tym - jak należy się spodziewać - i nad myślą administracyjną tego okresu.

We wprowadzeniu autor słusznie podkreśla, że „pojęcie myśli administracyjnej utrwaliło się już w polskiej nauce historyczno-prawnej, wyodrębniając się także jako zagadnienie badawcze" (s. 11). Na potwierdzenie tego faktu przytacza jednak w przypisie artykuł recenzyjny Wacława Uruszczaka z mojej rozprawy habilitacyjnej Polska myśl administracyjna XVIII wieku, w której jako pierwszy zastosowałem w opracowaniu naukowym termin „myśl administracyjna”, co wywołało wówczas krytykę między innymi ze strony wspomnianego autora recenzji5. Dodać wypada, że w 1979 roku utworzona została na Wydziale Prawa i Administracji UJ, z inicjatywy prof. Ludwika Łysiaka, pierwsza w Polsce Katedra Historii Administracji i Myśli Administracyjnej. Pojęcie to funkcjonowało natomiast już od lat 60. w nauce francuskiej (l'histoire de la pensée administrative $)^{6}$.

1 M. Gromadzka-Grzegorzewska, Narodziny polskich nauk administracyjnych, Warszawa 1985.

2 J. Malec, Polska myśl administracyjna XVIII wieku, Kraków 1986 (wyd. II: Kraków 2008).

3 P. Cichoń, Rozwój myśli administracyjnej w Księstwie Warszawskim 1807-1815, Kraków 2006.

4 M. Grzybowska, Decentralizacja i samorzad w II Rzeczypospolitej. Aspekty ustrojowo-polityczne, Kraków 2003; A. Bosiacki, Od naturalizmu do etatyzmu. Doktryny samorzadu terytorialnego Drugiej Rzeczypospolitej 1918-1939, Warszawa 2006; M. Sidor, Samorzad terytorialny w myśli politycznej II Rzeczypospolitej Polskiej, Toruń 2010. Brak jest niestety nadal opracowania, które podejmowałoby próbę oceny rozwoju historycznego nauki administracji w okresie II RP.

5 Por. W. Uruszczak, W sprawie dziejów polskiej myśli administracyjnej. Uwagi w zwiazku z praca Jerzego Malca, CPH 1987, t. 39, s. 187-198 oraz replika J. Malca, O recenzji Wacława Uruszczaka uwag kilka, CPH 1989, t. 41, z.1, s. 209-215.

6 P. Legendre, Histoire de la pensée administrative francaise [w:] Traité de science administrative, éd. J.M. Auby, Paris 1966. 
Celem, jaki przyświecał autorowi rozprawy, była analiza poglądów na kształt nowego ustroju administracyjnego, jakie formułowane były w toku - częściowo oficjalnych - prac prowadzonych z umocowania Aleksandra I w latach 1813-1815, a zatem do momentu nadania Królestwu regulacji konstytucyjnych. Zgodnie z przyjętym założeniem, z którym w pełni się zgadzam, eksploracji naukowej zostały poddane wszelkie powstające w tym czasie projekty (w szczególności aktów normatywnych) oraz wypowiedzi twórców reformy ustroju administracyjnego formułowane w toku prowadzonych prac. Tak bowiem rozumieć należy myśl administracyjną, w odróżnieniu od analizy konkretnych rozwiązań ustrojowych będących prawem obowiązującym.

Wspomniane prace prowadzone były w warunkach szczególnych. Formalnie istniało bowiem jeszcze Księstwo Warszawskie, choć faktycznie znajdowało się pod okupacją wojsk rosyjskich. Oczywiste było, że nowa władza nie zaaprobuje recepcji obowiązujących w Księstwie rozwiązań ustrojowych, opartych na modelu napoleońskiej Francji, a jednocześnie pewne regulacje wprowadzone po 1807 roku trudno było w pełni zastąpić anachronicznymi już $\mathrm{w}$ większości rozwiązaniami wywodzącymi się z epoki stanisławowskiej czy recepcją modelu opartego na Konstytucji 3 maja, mimo wyraźnej skłonności sporej części polskiej elity politycznej do takiej właśnie opcji.

W przeciwieństwie do epoki przedrozbiorowej, gdy nie istniała jeszcze myśl administracyjna w czystej postaci, a zagadnienia ustroju administracyjnego przewijały się w pracach i projektach traktujących o całości ustroju państwowego, w Księstwie Warszawskim oraz Królestwie Polskim powstawały już teksty poświęcone wyłącznie reformie administracji. Tym samym autor dysponował obszernym materiałem badawczym, który zebrał z wielką starannością, sięgając do źródeł rozproszonych po licznych archiwach krajowych i zagranicznych.

Podstawa źródłowa stanowi bardzo mocną stronę ocenianej monografii. Autor wykorzystał w pracy materiały niebędące dotąd przedmiotem badań. Są to obszerne protokoły posiedzeń Komitetu Cywilnego Reformy, gdzie toczono dyskusję nad kształtem przyszłego ustroju i gdzie dochodziło do ścierania się różnych poglądów odnośnie do modelu kształtowanej administracji publicznej. Bardzo ważnym źródłem są liczne projekty z lat 1814-1815 dotyczące administracji, które wyszły spod pióra takich autorów, jak Józef Kalasanty Szaniawski, książę Franciszek Ksawery Drucki-Lubecki, Andrzej Horodyski, Tadeusz Matuszewicz, Kajetan i Józef Koźmianowie, Franciszek Grabowski, Joachim Owidzki czy Antoni Bieńkowski. Nadto wykorzystano i poddano analizie akty prawne z 1815 roku dotyczące organizacji Rządu Tymczasowego, organizacji Ministerium Spraw Wewnętrznych, Ministerium Przychodów i Skarbu czy projekt ustroju administracyjnego zawarty w Ustawie konstytucyjnej Królestwa Polskiego, autorstwa Ludwika Platera. Zawarta na końcu bibliografia imponuje ilością przebadanego materiału, na który złożyły się źródła rękopiśmienne przechowywane w AGAD, Archiwach Państwowych w Kielcach, Lublinie, Łodzi i Poznaniu, w Bibliotece Jagiellońskiej, Bibliotece Książąt Czartoryskich w Krakowie, Bibliotekach PAN i PAU w Krakowie, Bibliotece Narodowej w Warszawie, Bibliotece Raczyńskich, Bibliotece Uniwersytetu Warszawskiego, Bibliotece Ossolineum we Wrocławiu, Bibliotece Towarzystwa Naukowego Płockiego oraz w archiwach rosyjskich w Moskwie i Petersburgu. Do tego dochodzą źródła drukowane i literatura przedmiotu (łącznie zestawienie liczy 30 stron druku). 
Podkreślić wypada, że autor omówił badane zagadnienie w sposób pełny i wyczerpujący, drobiazgowo analizując kompletny zasób archiwalny. W przyszłości z pewnością nie trzeba będzie już do tego tematu wracać celem uzupełnienia.

Także konstrukcja pracy i przyjęte metody badawcze nie budzą zastrzeżeń. Autor oparł swe rozważania na kryterium rzeczowym, co wydaje się w pełni uzasadnione, a rozmiary poszczególnych rozdziałów nie różnią się zbytnio między sobą.

W rozdziale pierwszym autor omawia rozwój administracji i myśli administracyjnej w Europie schyłku XVIII i początków XIX wieku, bowiem stanowiły one w znacznym stopniu inspirację twórców reformy przygotowywanej w Królestwie w latach 18131815. Kilka stron poświęcono także opisowi ustroju administracyjnego epoki stanisławowskiej. Nazbyt ogólnie - moim zdaniem - potraktowane zostały koncepcje reorganizacji administracji w tym okresie, czyli myśl administracyjna. A wysuwano wówczas szereg ciekawych i nowatorskich propozycji, jak choćby postulat stworzenia jednolitego systemu prawa policyjnego w Polsce ${ }^{7}$ czy wymóg kwalifikacji w sprawowaniu urzędów administracyjnych ${ }^{8}$, a nawet propozycje zaskarżalności decyzji administracyjnych do sądu, a zatem pierwowzór wykształconego w następnym stuleciu sądownictwa administracyjnego".

Głównym punktem rozważań są uwagi nad kształtem administracji w Księstwie Warszawskim, gdzie recypowano niemal w pełni francuski model zarządu oraz rozwiązania zawarte w tak zwanych litewskich projektach konstytucyjnych z lat 1811 i 1812. Co prawda w tym rozdziale autor nie wnosi wiele nowego do istniejącego stanu badan,

7 F. Nax, Uwagi nad uwagami, czyli obserwacje nad ksiażka, która w roku 1785 wyszła pod tytułem: Uwagi nad życiem Jana Zamoyskiego kanclerza i hetmana w. kor., Warszawa 1789, s. 42-45. Wspomnieć tu można także o anonimowej pracy Początkowe prawidta policji ogólnej w kraju, Warszawa 1792.

8 Zbiurokratyzowania administracji i wprowadzenia płatnej służby w jej organach domagali się Hieronim Stroynowski w pracy Nauka prawa przyrodzonego, politycznego, ekonomiki politycznej i prawa narodów (Wilno 1785, s. 136, 145-148) oraz Franciszek Czapski w pracy Dom nadwerężonej Rzeczypospolitej (1783, s. 73). Ks. August Sułkowski w projekcie pochodzącym z 1773 roku postulował nawet założenie specjalnej szkoły wyższej dla szlachty, w której nauczano by polityki, ekonomii oraz nauki moralności i która dostarczać by miała kandydatów do urzędów państwowych, w tym także administracyjnych (zob. S. Truchim, Augusta Sulkowskiego projekt organizacji szkolnictwa w Polsce, Warszawa 1932, s. 668-683). Również Józef Puszet w pracy O uszczęśliwieniu narodów (Warszawa 1788, s. 126-139), poświęcając rozdział XV rozdawnictwu urzędów, uważał, że od właściwego systemu ich obsadzania zależy w dużej mierze sprawność działania administracji. Twierdził, że osoba ubiegająca się o urząd administracyjny powinna legitymować się odpowiednimi kwalifikacjami; radził dopuścić do urzędów osoby stanu nieszlacheckiego oraz zakazać sprzedaży funkcji państwowych. Wreszcie autor rękopiśmiennego Projektu formy rządu narodu polskiego uzależniał piastowanie urzędów administracji wojewódzkiej od znajomości prawa, potwierdzonej ukończeniem odpowiedniej szkoły, oraz od dwuletniej praktyki administracyjnej. Pełna realizacja tych postulatów nastąpiła jednak dopiero w kolejnym stuleciu (por. J. Malec, Polska myśl administracyjna XVIII wieku..., s. 149).

9 Propozycje takie wyszły spod pióra Stanisława Siestrzencewicza, który postulował możliwość zaskarżania przez obywateli decyzji wydanych przez organy niższego szczebla do jednostek nadrzędnych: w pierwszej instancji do tzw. rządu wojewódzkiego, w drugiej - do Rady Nieustającej, zaś w trzeciej - w drodze apelacji bądź odesłania - do Trybunału (S. Siestrzencewicz, Ustawy na gubernie państwa catorossyjskiego, z ruskiego na polski język przetożone [...], które za wzór mogtyby być użyte albo do reformy, albo przynajmniej do poprawy rządu naszego wewnętrznego [w:] Serjarz projektów do prawa, innych różnych pism, uwag, myśli patriotycznych, żadań województw, ziem i powiatów, pomiędzy sejmem a sejmem od senatorów, posłów, gorliwych patriotów formowanych, t. II, Warszawa 1785, s. 579). Również Józef Kossakowski proponował powołanie najwyższej instancji sądowej, w której jeden z wydziałów odgrywałby rolę ,sądu administracyjnego", sądzącego w sprawach urzędniczych (J. Kossakowski, Obywatel, Warszawa 1788, s. 220-221). 
ale ma on znaczenie $\mathrm{z}$ uwagi na fakt inkorporowania, w większym bądź mniejszym stopniu, pewnych rozwiązań do projektów przygotowywanych w omawianym w pracy okresie późniejszym.

W rozdziale drugim zostały omówione prace nad reformą ustroju administracyjnego prowadzone przez Komitet Cywilny Reformy. Znalazło się tu także omówienie projektów przygotowywanych poza Komitetem, często przez samych jego członków. Szczególne znaczenie miał projekt Zasady konstytucji dla Królestwa Polskiego, przedstawiony do akceptacji cesarzowi, wytyczającemu wówczas ogólny kierunek prac nad reformą, bez ingerencji jednak bezpośrednio $\mathrm{w}$ jej kształt ${ }^{10}$. Był to bowiem okres, kiedy nie były jeszcze do końca znane przyszłe losy ziem wchodzących w skład Księstwa Warszawskiego, nadal formalnie istniejącego.

Kolejne rozdziały prezentują poglądy na poszczególne szczeble administracji rządowej. I tak w rozdziale trzecim ukazany został kształt rządu przyszłego Królestwa Polskiego, na czele którego stać miał suwerenny monarcha, którego podczas nieobecności zastępować miał namiestnik. Omówiony został tu także wpływ sejmu na administrację, w szczególności kształt instytucji odpowiedzialności konstytucyjnej ministrów, jak również status Rady Stanu (nie wiadomo, dlaczego w spisie treści nazwa tej instytucji pisana jest małymi literami).

Rozdział czwarty traktuje o centralnej administracji, czyli organizacji władz ministerialnych. Już na etapie prac projektowych w Zasadach konstytucji zaproponowano model zarządu kolegialnego, nawiązując tym samym do struktury wywodzącej się z tradycji epoki stanisławowskiej, w szczególności Konstytucji 3 maja. Nie bez znaczenia była tu rola, jaką w pracach tych odgrywał książę Adam Jerzy Czartoryski. Autor podkreśla jednak, że odwołanie się wprost do ustroju wprowadzonego Konstytucją 3 maja nie wchodziło $w$ grę $\mathrm{z}$ uwagi na opór samego cesarza, a także na fakt pozostawania w mniejszości zwolenników tej koncepcji. Z jednej strony większość opowiadała się już wówczas za modelem wprowadzonym w Księstwie Warszawskim. W szczególności, zdaniem M. Gałędka, dotyczyło to ograniczenia prerogatyw sejmu oraz supremacji monarchy w rządzie. $Z$ drugiej jednak strony uważam, że fakt odejścia od typowej dla systemu napoleońskiego zasady jednoosobowości administracji na wszystkich szczeblach administracji na rzecz kolegialnej struktury stanowił swoiste nawiązanie do modelu staropolskiego. Oczywiście administracja miała się opierać na zasadzie biurokratyzmu, która w epoce stanisławowskiej dopiero się kształtowała, a w Księstwie Warszawskim objęła wszystkie szczeble zarządu, jednak sam fakt przywrócenia zasady kolegialności wymaga - moim zdaniem - pełniejszego wyjaśnienia.

W rozdziale piątym autor przechodzi do omówienia koncepcji organizacji administracji szczebla wojewódzkiego. Także tutaj pojawiały się wyraźne nawiązania do ustroju z czasów Sejmu Czteroletniego, choćby w odniesieniu do projektu przywrócenia komisji porządkowych cywilno-wojskowych, różniących się jednak co do sposobu organizacji, zasad działania czy składu. I tu zatem wypada się zgodzić z autorem, że

10 Można domniemywać, że carowi Aleksandrowi I zależało wówczas przede wszystkim na pokazaniu Europie oblicza liberalnego i demokratycznego władcy, akceptującego ustrój konstytucyjny w państwie znajdującym się już pod jego faktyczną, choć jeszcze nie formalną władzą. W Imperium Rosyjskim natomiast wszelkie próby ograniczenia cesarskiego samodzierżawia na rzecz monarchii konstytucyjnej kończyły się krwawą kaźnią, jak choćby w przypadku powstania dekabrystów. 
na wierne kopiowanie rozwiązań wywodzących się z Sejmu Wielkiego było za późno, w nowej już epoce. Nie bagatelizowałbym jednak faktu czerpania z tradycji staropolskiej, choćby w nazewnictwie oraz wspomnianej kolegialności zarządu. W rozdziale tym mowa jest także o podziale terytorialnym na województwa (znów powrót do nazewnictwa przedrozbiorowego), kompetencjach władz wojewódzkich, ich zależności od rządu oraz wpływie na niższe szczebla administracji.

Rozdział szósty traktuje o administracji w obwodach, miastach i dominiach wiejskich, czyli na najniższych szczeblach podziału administracyjnego. Mowa tu o koncepcjach dotyczących powołania tak zwanych komisarzy obwodowych, a także o projektach nadających (można by rzec przywracających) samorządowy charakter władz miejskich oraz o urzędzie wójta.

Ostatni, siódmy, rozdział został poświęcony „stanowi urzędniczemu” (słusznie autor używa takiego nazewnictwa, bowiem termin „korpus urzędniczy” bardziej kojarzy się z epoką późniejszą) oraz biurokracji. Mowa tu o różnych poglądach na takie kwestie, jak obieralność, sprawy wynagradzania urzędników (lub pełnienia tych funkcji nieodpłatnie), kadencyjność urzędów, czynne i bierne prawo wyborcze z odniesieniem się do roli cenzusów majątkowych, wykształcenia i kwalifikacji zawodowych, do których przykładano coraz większą wagę, wreszcie dyscyplinarnej i karnej odpowiedzialności urzędników. Całość rozprawy kończy kilkunastostronicowe podsumowanie, w którym autor dokonuje reasumpcji głównych tendencji charakteryzujących przygotowywaną reformę administracji.

W większości wypada zgodzić się z wnioskami badawczymi zawartymi w zakończeniu. Autor potwierdza w swych wywodach dotychczasowe ustalenia nauki historycznoprawnej, zgodnie z którymi w pracach prowadzonych w latach 1813-1815 odwoływano się przede wszystkim do rozwiązań i doświadczeń wywodzących się z okresu Księstwa Warszawskiego, a nawiązywanie do ustroju administracyjnego epoki stanisławowskiej reprezentowane było przez zdecydowaną mniejszość autorów reformy. Ze swej strony uważam jednak - jak już wyżej wspomniałem - że nie należy całkowicie ignorować tego ostatniego wątku, bowiem przynajmniej w sferze nazewnictwa, a także pewnych zasad działania (kolegialność) był to wyraźny powrót do XVIII stulecia, gdzie zasada kolegialności dominowała $\mathrm{w}$ systemie administracji państw europejskich ${ }^{11}$. Bez wątpienia w pełni natomiast starano się oprzeć nową strukturę na zasadzie biurokratyzmu, która na ziemie polskie trafiła z nadejściem epoki napoleońskiej. Także pozostałe ustalenia autora dotyczące charakterystyki światopoglądowej twórców reformy, która mimo zróżnicowania wykazywała ostatecznie pewną homogeniczność, uważam za trafne.

Reasumując, wypada stwierdzić, że otrzymaliśmy książkę wartościową, ukazującą nieznane dotąd wątki myśli administracyjnej doby schyłku Księstwa Warszawskiego oraz początków Królestwa Polskiego. Autor zaprezentował się jako wytrawny badacz, o czym świadczyć może także jego wcześniejszy bogaty dorobek naukowy. Cieszy zarazem fakt zapełnienia kolejnej luki badawczej w nauce historycznoprawnej.

11 Nawet w samej Rosji w pierwszych latach XIX wieku oparto już zarząd centralny państwa na zasadzie jednoosobowości. J. Malec, D. Malec, Historia administracji i myśli administracyjnej, Kraków 2003, s. $128-130$. 


\section{Bibliografia}

[Anonim] Początkowe prawidta policji ogólnej w kraju, Warszawa 1792.

Bosiacki A., Od naturalizmu do etatyzmu. Doktryny samorzadu terytorialnego Drugiej Rzeczypospolitej 1918-1939, Warszawa 2006.

Cichoń P., Rozwój myśli administracyjnej w Księstwie Warszawskim 1807-1815, Kraków 2006.

Czapski F., Dom nadwerężonej Rzeczypospolitej, 1783.

Gromadzka-Grzegorzewska M., Narodziny polskich nauk administracyjnych, Warszawa 1985.

Grzybowska M., Decentralizacja i samorząd w II Rzeczypospolitej. Aspekty ustrojowo-polityczne, Kraków 2003.

Kossakowski J., Obywatel, Warszawa 1788.

Legendre P., Histoire de la pensée administrative francaise [w:] Traité de science administrative, éd. J.M. Auby, Paris 1966.

Malec J., O recenzji Wacława Uruszczaka uwag kilka, CPH 1989, t. 41, z. 1, s. 209-215.

Malec J., Polska myśl administracyjna XVIII wieku, Kraków 1986 (wyd. II: Kraków 2008).

Malec J., Malec D., Historia administracji i myśli administracyjnej, Kraków 2003.

Nax F., Uwagi nad uwagami, czyli obserwacje nad ksiązka, która w roku 1785 wyszła pod tytutem: Uwagi nad życiem Jana Zamoyskiego kanclerza i hetmana w. kor., Warszawa 1789.

Puszet J., O uszczęśliwieniu narodów, Warszawa 1788.

Sidor M., Samorząd terytorialny w myśli politycznej II Rzeczypospolitej Polskiej, Toruń 2010.

Siestrzencewicz S., Ustawy na gubernie państwa całorossyjskiego, z ruskiego na polski język przełożone [...], które za wzór mogłyby być użyte albo do reformy, albo przynajmniej do poprawy rządu naszego wewnętrznego [w:] Serjarz projektów do prawa, innych różnych pism, uwag, myśli patriotycznych, żądań województw, ziem i powiatów, pomiędzy sejmem a sejmem od senatorów, posłów, gorliwych patriotów formowanych, t. II, Warszawa 1785.

Stroynowski H., Nauka prawa przyrodzonego, politycznego, ekonomiki politycznej i prawa narodów, Wilno 1785.

Truchim S., Augusta Sulkowskiego projekt organizacji szkolnictwa w Polsce, Warszawa 1932.

Uruszczak W., W sprawie dziejów polskiej myśli administracyjnej. Uwagi w związu z praca Jerzego Malca, CPH 1987, t. 39, s. 187-198. 